July 15,1997

Is Bank Supervision Central to Central Banking?

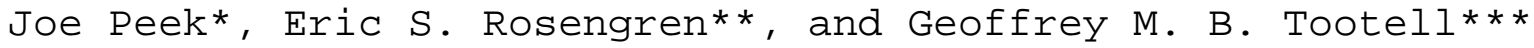

Abstract

Whether central banks should play an active role in bank supervision and regulation is being debated both in the United States and abroad. While the Bank of England has recently been stripped of its supervisory responsibilities and several proposals in the United States have advocated removing bank supervision from the Federal Reserve System, other countries are considering enhancing central bank involvement in this area. Many of the arguments for and against these proposals hinge on the effect this change would have on the ability of the central bank to conduct monetary policy. We find that confidential supervisory information on bank ratings significantly improves forecast accuracy of variables critical to the conduct of monetary policy, which supports the argument that central banks should have bank supervision responsibility. (JEL Codes: E52 E58)

*Department of Economics, Boston College, Chestnut Hill, MA 02167; (617) 552-3686; e-mail Peek@bc.edu

** Research Department T-8, Federal Reserve Bank of Boston, 600 Atlantic Avenue, Boston, MA 02106; (617) 973-3090; e-mail Eric.Rosengren@bos.frb.org

$\star \star \star$ Research Department T-8, Federal Reserve Bank of Boston, 600 Atlantic Avenue, Boston, MA 02106; (617) 973-3430; e-mail Geoff.Tootell@bos.frb.org

Valuable research assistance was provided by Faith KasiryeNsereko, Rokeya Khan, and Jonathon Willis. We thank Jeffrey Fuhrer, John Jordan, and Richard Kopcke for helpful comments. The views expressed are those of the authors, and do not necessarily reflect official positions of the Federal Reserve Bank of Boston or the Federal Reserve System. 
Is Bank Supervision Central to Central Banking?

"Our central bank must continue to have hands-on involvement in supervision and regulation in order effectively to carry out its macroeconomic responsibilities. Joint responsibilities make for better supervisory and monetary policy than would result from either a supervisor divorced from economic responsibilities or a macroeconomic policymaker with no involvement in the review of individual banks' operations."

Testimony by Federal Reserve Chairman Alan Greenspan before the Committee on Banking, Housing and Urban Affairs of the United States Senate, March 2, 1994.

"If the Federal Reserve were removed from the bank regulation process, would it have any significant impact on its ability to conduct monetary policy? My answer is: Clearly, it would not... It is clear that the primary role of the Federal Reserve is the conduct of monetary policy. That role is so important, I believe carrying out that function should not be diluted even slightly by having any of its resources diverted to any other function, including bank regulation."

Testimony by Donald Howard, former CFO Citicorp, before the Committee on Banking, Housing and Urban Affairs of the United States Senate, March 9, 1994.

While the importance of central bank independence for the conduct of monetary policy has been the subject of numerous empirical studies (for example, Cukierman 1992; Alesina and Summers 1993; Posen 1995; Fuhrer 1997), relatively little research has focused on the significance of other aspects of central banking, particularly its role in bank supervision. Recently, however, this role has received increased attention from policymakers. Although roughly three-quarters of OECD nations assign their central banks either total or shared responsibility for bank supervision, many of these countries are 
currently reviewing those responsibilities. For example, in mid1997 the Bank of England was given greater independence but was stripped of its bank supervisory responsibilities. In addition, policymakers in Japan are rethinking the role and responsibilities of the Bank of Japan in bank supervision. In all these countries, a key element of the debate about whether the central bank retained, or was given, supervisory duties has been whether these responsibilities contributed to the performance of monetary policy.

The United States has not been exempt from this controversy. Currently, the Federal Reserve System has partial responsibility for bank regulation, supervising bank holding companies and state member banks. Since 1994, a series of bills before Congress have proposed consolidating all bank supervisory responsibilities in a new single federal regulator, separate from the Federal Reserve. Proponents of such legislation have argued that bank supervision is a distraction for a central bank charged with a task as important as monetary policy. Opponents have argued that the information provided by bank supervision is vitally important to determining appropriate macroeconomic policies.

This paper tests whether information from bank supervision could substantially improve the ability of the Federal Reserve to conduct monetary policy. In particular, we examine whether data acquired through the Fed's role as a bank supervisor is useful in forecasting the macro variables of most concern to the Fed - the 
unemployment rate and the rate of inflation. ${ }^{1}$ Information based on confidential supervisory ratings is shown to substantially improve private sector forecasts of these variables. Given the central role of economic forecasting in guiding monetary policy, these results show that bank supervision does produce information useful for the formulation of monetary policy.

The next section discusses the role of central banks in bank supervision and why this role may provide useful information in the conduct of monetary policy. The second section describes the data. The third section presents the results; confidential supervisory ratings are shown to reduce the forecast errors of inflation and unemployment rates for a group of private forecasters. The final section discusses implications of central bank supervisory responsibilities for the conduct of monetary policy.

I. Background

Sargent and Wallace (1975), Barro (1976), and Fischer (1977) point out that in a world where expectations are formed rationally, there is room for effective and socially beneficial countercyclical monetary policy as long as the central bank possesses superior information to that available to the public. The source of this superior information is left unspecified. Since it is assumed that expectations are rational and that agents know the Fed's reaction function, the Fed's informational 
advantage must be about variables other than the future course of monetary policy that drive the economy.

Recently, Romer and Romer (1996) have provided empirical evidence about the existence of any informational advantage by the Federal Reserve. They examine whether the Fed's forecasts of the macroeconomy contain useful information not contained in private forecasts. Such a test is particularly appropriate, given that monetary policy affects the economy with long lags. Thus, forecasts of the economy are essential to the conduct of monetary policy, and, in fact, the Fed does react to its forecasts (McNees 1986; Tootell 1997). Consequently, a test that focuses on the informational content of central bank forecasts addresses a critical component of the implementation of monetary policy in the United States, analyzing data to assess future economic conditions to determine whether adjustments to monetary policy are necessary

Romer and Romer (1996) found that the Fed's macroeconomic forecasts contained information that would have proved useful to, and in fact often dominated, private forecasts, and that this superior information was not additional knowledge about the future course of monetary policy. Yet little research has been conducted on the potential sources of this informational advantage. This paper examines whether confidential banking data collected through the supervisory function might be the source of some of this informational advantage. 
Supervisory information may be useful for evaluating economic conditions and guiding monetary policy because problems in the banking sector may signal emerging problems in the rest of the economy. The role of banks in intermediating credit and interest rate risk, as well as their role in the payments system, may result in problems in the overall economy first becoming apparent in the banking system. Thus, troubles in the banking sector may provide an early indicator of problems outside the banking sector. Friedman and Kuttner (1992) and Bernanke (1990) have examined leading indicators for the economy and found an important role for financial variables. In general, these studies have examined publicly available interest rate spreads and interest rates; they have not explicitly included confidential supervisory ratings to capture problems in the banking sector.

A second possibility is that supervisory information may be important because of the role banks play in the economy. A number of studies have shown that the financial health of banks may affect either the response of the economy to a change in monetary policy instruments or the availability and terms of credit to borrowers, which could have broader implications for the overall economy (Bernanke 1983; Bernanke and Blinder 1988, 1992; Bernanke and Lown 1991; Peek and Rosengren 1995a, 1995b, 1995c; Kashyap and Stein 1994a, 1994b; Stein 1995; Kashyap, Stein, and Wilcox 1993; and Hancock and Wilcox 1992). 
To distinguish whether problems in the banking sector are only leading indicators of problems in the real economy or whether banking problems exacerbate problems in the real economy is beyond the scope of this paper. Rather, the goal of this research is to examine whether such confidential supervisory information is potentially useful to the central bank in the conduct of monetary policy. If so, the finding would strengthen the rationale for central bank involvement in bank supervision and address a major public policy issue currently being debated both in the United States and in other major OECD countries. If confidential supervisory information would have substantially reduced the forecast errors made by private forecasters that did not have access to the confidential information, then the central bank's role as bank supervisor provides information that can improve its ability to conduct effective monetary policy. Note that this informational advantage does not imply that private forecasters are making inefficient forecasts. Private forecasts still may be efficient, given the information available to the public, yet the importance of supervisory data would suggest that those private forecasts could be improved had they had the information set available to the central bank.

Testing this hypothesis requires examining the effect on private forecast errors of a variable that serves as a proxy for 
the supervisory information obtained by the Federal Reserve. The basic equation takes the following form:

$$
X_{t+i}=\alpha_{0}+\alpha_{1} E_{t}\left(X_{t+i}: I_{t}\right)+\alpha_{2} Z_{t}+e_{t},
$$

where $X_{t+I}$ is the realized future value of a vector of macroeconomic variables, $E_{t}\left(X_{t+i}: I_{t}\right)$ is a vector of the private forecasts of these variables conditioned on the information available at time $t$ when the forecasts are made, and $\mathrm{Z}_{\mathrm{t}}$ is $\mathrm{a}$ proxy variable for the confidential supervisory information available to bank supervisors at time $t$. If the confidential supervisory information provides no advantage to the Federal Reserve, $\alpha_{2}$ would equal zero. If $\alpha_{2}$ differs significantly from zero, then the confidential information obtained through bank supervision helps forecast the variables of concern to monetary policy. An important consequence of superior forecasts is the improved guidance they can provide to the Fed in conducting appropriate monetary policy

The measure of confidential supervisory information that we use is based on the CAMEL ratings used by bank examiners over the entire sample period to rate individual banks. The CAMEL scores given to banks are based on the five categories supervisors analyze when evaluating the health of a bank - Capital, $\underline{A} s$ sets, Management, Earnings, and Liquidity. ${ }^{2}$ Each bank is rated from 1, the highest, to 5, the lowest, on each of the component 
categories and given a composite rating. Banks with a 1 (sound in every respect) or 2 (fundamentally sound) rating are not likely to be constrained in any way by supervisory oversight. Banks with a 3 rating (flawed performance) are likely to have potential problems raised by examiners, but these problems are usually viewed as being correctable. Banks with a CAMEL rating of 4 (potential of failure, impaired viability) have a significant risk of failure. Banks with a CAMEL rating of 5 (high probability of failure, severely deficient performance) represent the set of banks with the most severe problems.

A large percentage of bank assets in the latter category could signal a weakening economy, for two reasons. First, the deteriorating economic conditions that resulted in the banking problems reflected in a poor CAMEL rating could be the leading edge of an impending economic slowdown, so that the CAMEL rating information serves as an early indicator of the downturn. Second, this set of banks, being the most deeply troubled, is likely to be subjected to the most severe supervisory intervention, with the resulting supervisory restrictions producing significant changes in bank policies, such as a sharp reduction in lending, that might contribute to a subsequent economic slowdown.

Two important points about the CAMEL data need to be highlighted. First, members of the Federal Open Market Committee (FOMC) keep abreast of the CAMEL ratings of the major banks. The 
Board of Governors review merger proposals, plans to engage in major asset purchases or sales, and requests to engage in new activities, with their approval contingent on how such changes will affect the safety and soundness (as well as antitrust and discrimination issues) of the involved banks. Through this process, members of the Board of Governors receive substantial and detailed information about emerging problems in the banking industry. A major component of any of these proposals will be a discussion of the current CAMEL ratings of the banks involved, reasons for any recent or impending changes in CAMEL ratings, and an overall assessment of bank health. Troubled institutions receive significant attention by the Board of Governors of the Federal Reserve system. In fact, a common reaction of new members of the Board is surprise over the amount of attention given to bank supervisory matters. Whether this time spent on supervisory issues is beneficial to the conduct of monetary policy will be examined below.

It is also important to note that the supervisory data are viewed as extremely confidential by each of the bank regulators. Until recently, the Federal Deposit Insurance Corporation (FDIC) had a policy of not disclosing the CAMEL rating even to bank management. Thus, neither the public nor any private forecasting agency would have access to the data. These data are the primary confidential assessments of individual bank health, the public release of which could be very damaging to an institution, 
particularly if it became widely known that examiners thought a bank had a very high probability of failure. While some assessment of banking problems can be deduced from publicly available financial statements, bank examiners have access to private bank information that is more comprehensive and more timely than the publicly available information. Note that if CAMEL ratings did not provide any additional information beyond publicly available data, the estimated coefficient on the confidential supervisory information in equation 1 would be insignificant, and there would be little evidence to suggest that the Federal Reserve, or anyone else for that matter, could gain an informational advantage by being involved in supervisory activities.

II. Data

The macroeconomic variables that are the focus of this study are the unemployment rate and the Consumer Price Index (CPI) inflation rate. Most models of the Federal Reserve objective function, from Theil (1964) to Kydland and Prescott (1977) and Walsh (1995), include these two variables. The use of these two variables has an added benefit. The CPI inflation rate is not revised subsequently, and the unemployment rate is revised only marginally, when seasonals are updated. ${ }^{3}$

This study examines the one-, two-, three-, and fourquarter-ahead forecast errors of inflation and unemployment rates 
of three major commercial forecasters: Data Resources, Inc.McGraw Hill (DRI), Georgia State University (GSU), and the University of Michigan Research Seminar in Quantitative Economics (RSQE) . All three forecasters sell their forecasts commercially and have generally been among the forecasters with the best forecast record for the macroeconomic variables examined in this study (MCNees 1992). Both RSQE and GSU provide quarterly forecasts that generally are released in the middle month of each quarter. DRI provides forecasts monthly, and we use their forecast for the middle month of each quarter so that all forecasts possess roughly the same information set. The sample period begins in 1978:I, since the CAMEL data first became available only in late 1977, and ends in 1996:II. Only two of the individual forecasters, DRI and RSQE, have forecasts available as far back as 1978:I. The GSU forecasts begin in 1980 : III.

An example will serve to make clear how the timing issues have been resolved. The one-quarter-ahead forecasts would correspond to forecasts of the unemployment rate and the inflation rate for the first quarter of 1990 made as of the middle of 1990:I or, in the case of the monthly DRI forecasts, as of February 1990. The two-quarter-ahead forecasts made as of the middle of the first quarter of 1990 would be for values of the unemployment rate and the inflation rate in 1990:II, and so on. It should be emphasized that each forecast is for a single 
quarter, with the one-, two-, three-, and four-quarter-ahead forecasts differing in their distance from the date at which the forecast is made, not in the length of the period being forecast. One benefit of the timing of the forecasts is that by the middle of the quarter, forecasters know the actual values of the unemployment rate and the inflation rate for the prior quarter. Although this timing convention eliminates any concern about introducing a moving-average process into the forecast errors for the one-quarter-ahead forecasts, the possibility of a movingaverage term in the error of equation 1 still exists for the more distant quarters most relevant to monetary policy: the two-, three- and four-quarter-ahead forecasts. ${ }^{4}$

In addition to the three individual forecasts, we also examine the Blue Chip consensus forecast, which is an average of 50 individual forecasts. Since these forecasts are provided monthly, like DRI's, the Blue Chip forecast for the middle month of each quarter is used. The forecasts begin in 1980:I. Since, as Keene and Runkle (1990) point out, ordinary least squares (OLS) estimation produces inconsistent estimates of the standard errors when forecast errors are correlated across forecasters within a consensus forecast, the Blue Chip consensus is used only as a standard for comparison. ${ }^{5}$ One reason to use the Blue Chip for comparison is that McNees (1992) has found that it performs as well as individual forecasts when comparing the mean squared error of the forecasts. 
The variable that serves as a proxy for the confidential bank data available to the central bank (CAMEL5) is the percentage of assets in commercial banks rated CAMEL 5 as of the end of the month prior to the forecast. This information on the most troubled banks is known to the Federal Reserve at the time the private forecasts are made. Given that a high CAMEL rating indicates weakness in the banking sector, the estimated coefficient on CAMEL5 should be positive for the unemployment rate equation and negative for the inflation rate equation if it contains significant information about the economy not included in the commercially available forecasts.

One problem with examining forecasts over this period is the presence of substantial oil price shocks. While the unemployment rate is a relatively smooth series, showing little reaction to these oil supply shocks, movements in the quarterly CPI inflation rate do reflect the sharp increases in oil prices associated with the second OPEC supply shock in 1979 and the Gulf War in 1990, as well as the collapse in oil prices in 1986. Ideally, we would examine the core rate of inflation, since supervisory information is unlikely to be useful in explaining externally generated supply shocks. Unfortunately, several forecasters do not report core inflation rates back to the late 1970s. Thus, comparing the forecast error for the total CPI to the measure of supervisory information is a stringent test, since the supervisory data will not explain any of the largest CPI errors - those when oil prices 
changed unexpectedly due to external factors. Consequently, we reestimated each of the regressions including a set of dummy variables for those observations when oil prices rose or fell sharply. ${ }^{6}$ For the inflation equations, including these oil shock dummy variables tended to strengthen the significance levels on the t-statistics for the variable of interest here, CAMEL5. ${ }^{7}$

\section{Empirical Results}

Table 1 provides the OLS regression results for the unemployment rate and the CPI inflation rate for a sample formed by pooling the data for the three individual forecasters (DRI, GSU, and RSQE). For the unemployment rate, the estimated coefficient on the forecast for each of the four quarters has a value close to one and is statistically significant. ${ }^{8}$ The estimated coefficient on the proxy for supervisory information (CAMEL5) is also both positive and significant in each equation. The positive sign on the estimated coefficient indicates that as a larger share of bank assets is accounted for by CAMEL 5-rated banks, the unemployment rate rises relative to private forecasts of it. This is consistent with the absence of the confidential supervisory information from the information sets of private forecasters, causing those forecasters to underpredict the unemployment rate by a greater degree, the larger is CAMEL5. The significance of the CAMEL5 estimated coefficients indicates that supervisory data appear to provide information 
that can improve upon private forecasts of the unemployment rate at all four horizons. In fact, the estimated coefficients rise (in absolute value) as the quarter being forecast becomes more distant. For example, the estimated coefficient on CAMEL5 for the two-quarter-ahead forecast is nearly twice that for the equation based on the one-quarter-ahead forecast, and the estimated coefficients for the three- and four-quarter-ahead forecasts are almost three times that of the one-quarter-ahead forecast. The increased importance of the supervisory information as the horizon becomes more distant suggests that the supervisory information may become even more valuable at the longer horizons most relevant for monetary policy.

The results are qualitatively similar for the inflation forecast equations. For the one-quarter-ahead inflation forecast, the estimated coefficient on CAMEL5 is negative, as predicted, but is not significant. However, when the forecast horizon shifts to the more distant two-, three-, and fourquarter-ahead forecasts, the estimated coefficients are each significant. As was the case with the unemployment forecast equations, the estimated coefficient on CAMEL5 is larger, the more distant is the quarter being forecast, with the increase in the size of the coefficient even more dramatic than for the unemployment rate equations. The coefficient on the measure of supervisory information for the two-quarter-ahead forecast is more than three times as large as that for the one-quarter-ahead 
forecast, and those for the three- and four-quarter-ahead forecasts are more than six times as large.

A problem with the estimates presented in Table 1 is that when the data set is formed by pooling the data for the three individual forecasters, OLS estimation produces consistent estimates for the coefficients, but inconsistent estimates of the standard errors. OLS estimation ignores the potential contemporaneous correlations across individual forecast errors due to shocks to the economy not anticipated by all the forecasters. Consistent estimates of the standard errors require that the estimation account for this property of the covariance structure of the forecast errors. Furthermore, as noted earlier, the two-, three-, and four-quarter-ahead forecasts would be expected to have forecast errors that follow a moving-average process.

Table 2 provides the results of estimating the regressions for the pooled sample of individual forecasters after correcting for the moving-average and contemporaneous correlations by adjusting the covariance matrices to achieve efficient estimates using the procedure described by Keene and Runkle (1990). The consistent estimates of the standard errors are significantly larger than those produced by the OLS estimation. Still, the estimated coefficients on the measure of supervisory information remain statistically significant in the unemployment rate equations for each of the four forecast horizons, as in Table 1. 
The estimated coefficients on CAMEL5 for the three- and fourquarter-ahead inflation rate forecast equations also remain significant. ${ }^{9}$

A particularly reassuring characteristic of the coefficient patterns on CAMEL5 is the tendency for the coefficient estimates to rise as we move from the one-quarter-ahead forecast to the four-quarter-ahead forecast. This pattern is consistent with the effect of an economic shock initially growing over time as it feeds through the economy. Furthermore, the fact that the effect appears to be delayed slightly more in the inflation equations than in the unemployment equations is consistent with a large number of models: for example, standard estimates of the Phillips curve imply that the real economy tends to react earlier than do prices.

Supervisory Information, Forecaster by Forecaster

The much larger sample size generated by pooling the individual forecaster data enhances the power of the test. Nonetheless, one might still want to consider the results obtained by estimating separate equations for each individual forecaster. Even though the much smaller sample size is likely to substantially reduce the t-statistics on the estimated coefficients, the size of the estimated coefficients can provide a feel for the extent to which the results in Table 2 might be generated primarily by aberrations associated with the data from 
only one of the forecasters. It would be reassuring if each of the individual forecasters, as well as the Blue Chip consensus forecasts, provided similar point estimates for the CAMEL5 coefficients.

Table $3 \mathrm{~A}$ provides the results for the unemployment rate, with separate equations estimated for each individual forecaster included in the pooled results in Table 2 as well as for the consensus Blue Chip forecasts. The standard errors are adjusted for the relevant moving-average processes. Since the data for the individual forecasters are not pooled, the contemporaneous cross-correlations are no longer an issue. The results are strikingly similar across forecasters. The estimated coefficients on CAMEL5 are significant for each of the four forecasters for the one-quarter-ahead forecasts of the unemployment rate. Furthermore, the separately estimated coefficients for each forecaster are of a similar magnitude, indicating that the pooled results in Table 2 reflect a consistency across the separate private forecasters.

For the equations based on the two-, three- and fourquarter-ahead unemployment rate forecasts, the estimated coefficient patterns for the measure of supervisory information are also quite consistent, both across forecasters and compared to the estimates in Table $2 .{ }^{10}$ The coefficient estimates are significant for three of the four forecasters for the twoquarter-ahead forecasts, and for all four of the three-quarter- 
ahead forecasts. For the four-quarter-ahead forecasts, RSQE and the Blue Chip equations have CAMEL5 effects that are significant at traditional levels, while that for DRI is significant at the 10 percent level. Furthermore, the coefficient estimates for each of the forecasters exhibit the same pattern as shown in Table 2, with the coefficients generally rising as the quarter being forecast becomes more distant. The generally reduced significance levels for the CAMEL5 coefficients for the individual forecasters compared to those in the pooled sample in Table 2 reflect in large part the fact that the power of the test has been reduced substantially relative to that for the pooled sample. However, these estimates do highlight that the significant coefficients on CAMEL5 in Table 2 are not due to a single forecaster. Rather, the coefficient patterns are produced consistently across each of the separate sources of private forecasts.

Table 3B shows the results for the inflation rate when separate equations are estimated for each of the individual forecasters. With only one exception, the coefficients on the measure of supervisory information for each forecaster at each horizon are correctly signed. The coefficients for the individual forecasters also exhibit the same pattern of the estimated coefficients increasing in magnitude as the forecast quarter becomes more distant. However, the estimated coefficients on CAMEL5 are significantly different from zero only 
for the three- and four-quarter-ahead horizons for GSU and for the four-quarter-ahead horizon for DRI. Nevertheless, the results for the individual forecasters confirm the patterns shown in the regressions based on the pooled sample. The confidential information contained in CAMEL5 does appear to add to the explanatory power of the information set used by private sector forecasters, although (as expected) the t-statistics are much weaker when the sample size is so sharply reduced by estimating separate equations for each forecaster.

\section{Supervisory Data and Bank Crises}

Several earlier studies have indicated that the late 1980s and early 1990s may have been unusual, with bank failure rates not seen since the Great Depression. Thus, one might wonder whether the explanatory power found for the supervisory data is derived only from this extreme banking crisis. In other words, while it may be very important for the central bank to have such bank supervisory information during a banking crisis, it might be much less important during periods when fluctuations in bank health are less extreme.

Is such information useful when events are more moderate? To answer this question, we reestimated the equations reported in Table 2, excluding the period from 1988:II to 1991:III. These end-points were chosen because 1988:II is the period when the value of CAMEL5 began to climb and 1991:III marks the end of the 
recession, using NBER recession dates; by that time banks had begun to show improved financial health. Omitting this period removes the subperiod containing the largest movement in CAMEL5 values. Nonetheless, the economy before 1988:II experienced banking problems in the oil-producing and agricultural states, while after 1991:III the banking sector had problems in California.

The effect of supervisory data on the forecast errors for the unemployment rate even over this restricted sample, shown in Table 4, is similar to the effect reported in Table 2 . When the subperiod containing the most severe banking problems is excluded, the estimated coefficients on CAMEL5 for the onequarter-ahead and two-quarter-ahead forecasts are 0.091 and 0.174, respectively, virtually identical to the results over the entire period of 0.091 and 0.175 . Although the standard errors are now larger, the estimated coefficients are still significant. The coefficients for the three- and four-quarter-ahead forecasts are smaller than those shown in Table 2, although they remain larger than that on the one-quarter-ahead forecast, and the standard errors are larger, perhaps due to the reduced sample size, so that the coefficients are no longer significant at the 5 percent level.

The results for the inflation rate equations are somewhat stronger when the period of the most severe banking problems is excluded. The CAMEL5 coefficient for the one-quarter-ahead 
forecast equation changes from -0.141 to -0.227 , while that for the two-quarter-ahead forecast equation changes from -0.468 to -0.731. For the three- and four-quarter-ahead forecasts, the coefficients also are larger (in absolute value) than those in Table 2. The measure of supervisory information adds significantly to the forecasting ability of the equations at the two-, three-, and four-quarter-ahead forecast horizons. Thus, the results for inflation are actually stronger in Table 4 than Table 2, in part because the period omitted includes the Gulf War oil shock that produced some of the largest forecast errors for inflation during the 1978:I to 1996:II period under consideration.

It is reassuring to find such similarity in the coefficient patterns between Tables 2 and 4, and to find that the power of the test was not seriously eroded by the exclusion of so much of the data, particularly since the excluded subperiod contained the most severe banking problems and the most extreme values of CAMEL5. These results, like those for the unemployment rate equations, indicate that the information gained by the central bank from its supervisory authority may be useful for the conduct of monetary policy even when the economy is not experiencing severe banking problems. 
IV. Conclusion

This study shows that confidential bank supervisory information is highly correlated with the forecast errors of private forecasters who do not have access to bank CAMEL ratings. Periods with a high percentage of bank assets in CAMEL 5-rated banks are associated with forecasters underpredicting the unemployment rate and over predicting the inflation rate. Furthermore, the estimated coefficients tend to rise as the quarter being forecast becomes more distant, consistent with the effects of bank problems cumulating over time. The results are qualitatively similar whether separate equations are estimated for the individual forecasters or the data are pooled. Finally, the patterns of coefficient estimates found for the whole period remain in the data even if we exclude the late 1980s and early 1990s period when the share of bank assets in CAMEL 5-rated institutions was at its peak. Thus, not only is supervisory information valuable during periods of banking problems, it also contributes to the ability to forecast the inflation and unemployment rates even in noncrisis periods.

Does the usefulness of the supervisory data in forecasting the inflation rate and the unemployment rate require that the central bank actually have bank supervisory powers, and thus collect the data itself, to conduct monetary policy most efficiently? The empirical results cannot directly address this issue but, for several reasons, it might be costly for this nexus 
of regulation and monetary policy to be broken. We use the share of assets held by CAMEL 5-rated institutions as a proxy variable for banking problems known to bank supervisors but not known to private forecasters. We have included the CAMEL rating measure as our instrument because it is the primary quantifiable variable produced by the examination process, but it certainly does not comprise all the information available to bank supervisors.

Although it may be possible to obtain this information without direct supervisory responsibility, it likely would be costly to separate supervisory and monetary policy responsibilities, unless the central bank continues to be fully apprised of all information obtained through the examination process. ${ }^{11}$ While this point is relevant in developed as well as developing countries, it is particularly so in countries with less developed capital markets that have been especially hard hit by the simultaneous occurrence of banking and economic crises (Caprio and Klingebiel 1996). The supervisory information in those countries not only may be useful in forecasting the economy in general, but may be particularly critical to other important functions of the central bank such as maintaining the payments system and crisis management, given the much larger role played by banks in their credit markets. Our results indicate that access to all the information available through bank exams should be important considerations as countries consider the role of their central bank. 
While this study finds that confidential CAMEL ratings provide potentially useful information for forecasting unemployment and inflation for the Federal Reserve, it does not address why this information is useful. Supervisory information may signal nonbank problems not currently incorporated into private forecasts. Alternatively, liability or asset management by troubled banks may alter the transmission of monetary policy . Identifying why supervisory data provide such useful information in forecasting inflation and unemployment, and whether these findings extend to other countries, should be a productive area for future research. 
References

Alesina, Alberto, and Lawrence Summers. 1993. "Central Bank Independence and Macroeconomic Performance: Some Comparative Evidence." Journal of Money, Credit, and Banking, 25 (2), $151-62$.

Barro, Robert J. 1976. "Rational Expectations and the Role of Monetary Policy." Journal of Monetary Economics, vol. 2, January, 1-32.

Bernanke, Ben S. 1983. "Nonmonetary Effects of the Financial Crisis in the Propagation of the Great Depression." The American Economic Review, 73, June, 257-76.

- 1990. "On the Predictive Power of Interest Rates and Interest Rate Spreads." New England Economic Review, November/December, 51-68.

Bernanke, Ben S., and Alan S. Blinder. 1988. "Credit, Money, and Aggregate Demand." The American Economic Review, 78, May, 435-39. 1992. "The Federal Funds Rate and the Channels of
Monetary Transmission." The American Economic Review, 82,
901-21.

Bernanke, Ben S., and Cara S. Lown. 1991. "The Credit Crunch." Brookings Papers on Economic Activity, No. 2, 205-48.

Caprio, Gerard, Jr., and Daniela Klingebiel. 1996. "Bank Insolvencies: Cross Country Experiences." The World Bank Policy Research Working Paper No. 1620, July.

Cukierman, Alex. 1992. Central Bank Strategy, Credibility, and Independence: Theory and Evidence. Cambridge, MA: The MIT Press.

Fischer, Stanley. 1977. "Long-Term Contracts, Rational Expectations, and the Optimal Money Supply Rule." Journal of Political Economy, 85(1), 191-205.

Friedman, Benjamin M., and Kuttner, Kenneth N. 1992. "Money, Income, Prices, and Interest Rates." The American Economic Review, 82, June, 472-92. 
Fuhrer, Jeffrey C. 1997. "Central Bank Independence and Inflation Targeting: Monetary Policy Paradigms for the Next Millennium?" New England Economic Review, January/February, 19-36.

Hancock, Diana, and James A. Wilcox. 1992. "The Effects on Bank Assets of Business Conditions and Capital Shortfalls." In Credit Markets in Transition, Proceedings of the 28th Annual Conference on Bank Structure and Competition, Chicago: Federal Reserve Bank of Chicago, 502-20.

Hansen, L. P., and R. J. Hodrick. 1980. "Forward Exchange Rates As Optimal Predictors of Future Spot Rates: An Econometric Analysis." Journal of Political Economy, 88, 829-53.

Kashyap, Anil K. and Jeremy C. Stein. 1994a. "Monetary Policy and Bank Lending." In N. Gregory Mankiw, ed., Monetary Policy, Chicago, IL: University of Chicago Press, 221-56.

- 1994b. "The Impact of Monetary Policy on Bank Balance Sheets." Carnegie-Rochester Conference Series on Public Policy, 42, June, 151-95.

Kashyap, Anil K., Jeremy C. Stein, and David W. Wilcox. 1993. "Monetary Policy and Credit Conditions: Evidence from the Composition of External Finance." The American Economic Review, 83, March, 78-98.

Keene, Michael P. and David E. Runkle. 1990. "Testing the Rationality of Price Forecasts: New Evidence from Panel Data." The American Economic Review, 80, September, 714735 .

Kydland, Finn and Edward Prescott. 1977. "Rules Rather than Discretion: The Inconsistency of Optimal Plans." Journal of Political Economy, 85(3), June, 473-91.

McNees, Stephen K. 1986. "Modeling the Fed: A Forward-Looking Monetary Policy Reaction Function." New England Economic Review, November/December, 3-8.

- 1992. "How Large Are Economic Forecast Errors?" New England Economic Review, July/August, 25-42.

Peek, Joe and Eric S. Rosengren. 1995a. "Bank Lending and the Transmission of Monetary Policy." In Joe Peek and Eric S. Rosengren, eds., Is Bank Lending Important for the Transmission of Monetary Policy? Federal Reserve Bank of Boston conference Series No. 39, 47-68. 
- 1995b. "Bank Regulation and the Credit Crunch." Journal of Banking and Finance, 19(1), June, 679-92.

- 1995c. "The Capital Crunch: Neither a Borrower nor a Lender Be." Journal of Money, Credit, and Banking, 27 (3), August, 625-38.

Posen, Adam. 1995. "Central Bank Independence and Disinflationary Credibility: A Missing Link?" Federal Reserve Bank of New York Staff Reports, No. 1, May.

Romer, Christina D. and David H. Romer. 1996. "Federal Reserve Private Information and the Behavior of Interest Rates." NBER Working Paper No. 5692, July.

Sargent, Thomas J., and Neil Wallace. 1975. "'Rational' Expectations, the Optimal Monetary Instrument, and the Optimal Money Supply Rule." Journal of Political Economy, $83(2), 241-54$.

Stein, Jeremy C. 1995. "An Adverse Selection Model of Bank Asset and Liability Management with Implications for the Transmission of Monetary Policy." NBER Working Paper No. 5217, August.

Theil, Henri. 1964. Optimal Decision Rules for Government and Industry, 2nd ed., North-Holland, Amsterdam.

Tootell, Geoffrey M. B. 1997. "How Far-Sighted is the FOMC?" New England Economic Review, January/February, 49-65.

Walsh, Carl E. 1995. "Optimal Contracts for Central Bankers." The American Economic Review, 85 (1), March, 150-67. 


\section{Endnotes}

1. While forecasting economic activity is a critical component of the conduct of monetary policy, the information obtained through its bank supervisory role also can make important contributions to other dimensions of central bank

responsibilities. Among these responsibilities are avoiding serious disruptions to the payment system, avoiding systemic problems emanating from the banking sector, and serving as lender of last resort. While these are important issues in the United States, they may take on even greater importance in countries with less developed financial markets.

2. On January 1, 1997, the CAMEL rating system was expanded to CAMELS. The S stands for "sensitivity to market risk," and is intended to measure how well prepared a bank is to handle changes in interest rates, exchange rates, and commodity or equity prices.

3. These two series avoid the serious problem of forecasting a variable using one set of base year relative prices and comparing it to an actual realization that uses another set, which occurs with the GDP forecasts when the base year changes.

4. Hansen and Hodrick (1980) point out that the errors over longer forecast horizons should follow predictable moving-average processes. In this study, since the forecasts are for nonoverlapping quarters, the moving average process is not introduced by construction. Rather, the moving average processes occur because a shock that arises subsequent to the time at which the quarterly forecasts are made is likely to have persistent effects.

5. The inconsistency caused by this correlation across forecasters could be corrected if each forecaster's quarterly forecast were given in the Blue chip. Unfortunately, the quarterly forecasts are provided only for the consensus forecast. Only the annual forecasts are provided for the individual forecasters.

6. The results presented here do not include the oil shock dummy variables, since quantifying the precise quarters the oil shocks occurred is somewhat subjective. We include two dummy variables to control for oil shocks. The first one has a value of one associated with forecasts of unemployment and inflation rates for 1979:I through 1979:IV and for 1990:III, the periods of large oil price increases associated with the second OPEC price shock and the outbreak of the Gulf War, and zero otherwise. The second dummy variable has a value of one associated with 
forecasts for 1986:I, when oil prices collapsed, and zero otherwise. To avoid concerns that the results are predicated on the periods we selected, we simply provide the results from the regressions that do not include the oil shock dummy variables. Omitting the dummy variables only increases the probability that the results would find no effect for the supervisory information.

7. In addition, we find that the moving-average terms tend to be less important when controlling for the oil shocks, much of whose effect was not anticipated by forecasters and accounts for most of the largest forecast errors in the inflation equation.

8. The standard efficiency test of the forecast, testing whether the constant is zero and the coefficient on the forecast is equal to one, is no longer valid for our specification. First, the null hypothesis for this efficiency test would assume that the forecasters have the confidential supervisory information, which is false. Second, as will be discussed later, the standard error estimates are inconsistent.

9. If one includes the oil supply shock dummy variables in the inflation forecast equations, the CAMEL5 coefficient in the twoquarter-ahead forecast equation also is significant.

10. Note that some of the differences in the coefficient estimates across forecasters may be attributable to the fact that they differ in the sample period they cover. The DRI and RSQE samples begin in 1978:I, while Blue Chip and GSU begin in 1980:I and 1980:III, respectively.

11. The CAMEL data are only useful if the Federal Reserve understands how the rating is formulated and how the rating process may be changing. The Federal Reserve not only regulates the holding company and state member banks, it frequently jointly conducts examinations with other regulators. This provides information not only about the banks, but also about how other regulators are rating banks and conducting exams. 
Table 1

Contribution of Confidential Bank Supervisory Information to the Forecast Accuracy for the Unemployment and Inflation Rates Estimation Method: Ordinary Least Squares

\begin{tabular}{|c|c|c|c|c|c|c|c|c|}
\hline \multirow[b]{2}{*}{ Variable } & \multicolumn{4}{|c|}{ Unemployment Rate } & \multicolumn{4}{|c|}{ Inflation Rate } \\
\hline & $1 \mathrm{Q}$ & $2 \mathrm{Q}$ & $3 \mathrm{Q}$ & 4Q & $1 \mathrm{Q}$ & $2 \mathrm{Q}$ & $3 \mathrm{Q}$ & 4Q \\
\hline Constant & $\begin{array}{c}.018 \\
(.053)\end{array}$ & $\begin{array}{c}.126 \\
(.127)\end{array}$ & $\begin{array}{c}.199 \\
(.212)\end{array}$ & $\begin{array}{c}.304 \\
(.276)\end{array}$ & $\begin{array}{c}.398 \\
(.237)\end{array}$ & $\begin{array}{c}.767 \\
(.398)\end{array}$ & $\begin{array}{c}1.138^{*} \\
(.485)\end{array}$ & $\begin{array}{l}1.501^{* *} \\
(.559)\end{array}$ \\
\hline Forecast & $\begin{array}{l}.979 * * \\
(.008)\end{array}$ & $\begin{array}{l}.945^{* *} \\
(.019)\end{array}$ & $\begin{array}{l}.927 * * \\
(.031)\end{array}$ & $\begin{array}{l}.910 * * \\
(.041)\end{array}$ & $\begin{array}{l}.925^{* *} \\
(.029)\end{array}$ & $\begin{array}{l}.928 * * \\
(.054)\end{array}$ & $\begin{array}{l}.922 * * \\
(.072)\end{array}$ & $\begin{array}{l}.820 * * \\
(.083)\end{array}$ \\
\hline CAMEL5 & $\begin{array}{l}.091 * * \\
(.013)\end{array}$ & $\begin{array}{l}.175^{* *} \\
(.030)\end{array}$ & $\begin{array}{l}.240^{* *} \\
(.048)\end{array}$ & $\begin{array}{l}.258^{* *} \\
(.060)\end{array}$ & $\begin{array}{l}-.141 \\
(.116)\end{array}$ & $\begin{array}{l}-.468^{* *} \\
(.180)\end{array}$ & $\begin{array}{l}-.926^{* *} \\
(.199)\end{array}$ & $\begin{array}{l}-.997 * * \\
(.215)\end{array}$ \\
\hline $\mathrm{R}^{2}$ & .988 & .933 & .831 & .736 & .851 & .642 & .522 & .426 \\
\hline SSR & 4.22 & 24.16 & 62.05 & 98.43 & 341.7 & 821.2 & $1,057.0$ & $1,222.7$ \\
\hline SER & . 142 & .340 & .545 & .686 & 1.279 & 1.982 & 2.249 & 2.419 \\
\hline
\end{tabular}

Standard errors are in parentheses.

* Significant at the 5 percent level.

**Significant at the 1 percent level. 
Table 2

Contribution of Confidential Bank Supervisory Information to the Forecast Accuracy for the Unemployment and Inflation Rates, Corrected for Moving Average and Contemporaneous Correlations

\begin{tabular}{|c|c|c|c|c|c|c|c|c|}
\hline \multirow[b]{2}{*}{ Variable } & \multicolumn{4}{|c|}{ Unemployment Rate } & \multicolumn{4}{|c|}{ Inflation Rate } \\
\hline & $1 \mathrm{Q}$ & $2 Q$ & $3 \mathrm{Q}$ & 4Q & $1 \mathrm{Q}$ & $2 \mathrm{Q}$ & $3 \mathrm{Q}$ & $4 \mathrm{Q}$ \\
\hline Constant & $\begin{array}{c}.018 \\
(.078)\end{array}$ & $\begin{array}{c}.126 \\
(.252)\end{array}$ & $\begin{array}{c}.199 \\
(.477)\end{array}$ & $\begin{array}{c}.304 \\
(.564)\end{array}$ & $\begin{array}{c}.398 \\
(.325)\end{array}$ & $\begin{array}{c}.767 \\
(.682)\end{array}$ & $\begin{array}{l}1.138 \\
(.910)\end{array}$ & $\begin{array}{c}1.501 \\
(1.073)\end{array}$ \\
\hline Forecast & $\begin{array}{l}.979 * * \\
(.012)\end{array}$ & $\begin{array}{l}.945^{* *} \\
(.038)\end{array}$ & $\begin{array}{l}.927 * * \\
(.071)\end{array}$ & $\begin{array}{l}.910^{* * *} \\
(.082)\end{array}$ & $\begin{array}{l}.925 * * \\
(.038)\end{array}$ & $\begin{array}{l}.928 * * \\
(.089)\end{array}$ & $\begin{array}{l}.922 * * \\
(.132)\end{array}$ & $\begin{array}{l}.820 * \\
(.155)\end{array}$ \\
\hline CAMEL5 & $\begin{array}{l}.091 * * \\
(.019)\end{array}$ & $\begin{array}{l}.175^{* *} \\
(.059)\end{array}$ & $\begin{array}{c}.240 * \\
(.103)\end{array}$ & $\begin{array}{c}.258^{*} \\
(.125)\end{array}$ & $\begin{array}{l}-.141 \\
(.161)\end{array}$ & $\begin{array}{l}-.468 \\
(.314)\end{array}$ & $\begin{array}{l}-.926^{*} \\
(.380)\end{array}$ & $\begin{array}{l}-.997 * \\
(.414)\end{array}$ \\
\hline
\end{tabular}

Note: The standard errors in the two quarter-ahead-forecast equation are corrected for MA(1) errors; the three-quarter-ahead-forecast equation is corrected for MA(1) and MA(2) errors; and the four-quarter-ahead forecast equation is corrected for $\mathrm{MA}(1), \mathrm{MA}(2)$, and $\mathrm{MA}(3)$ errors.

Standard errors are in parentheses.

* Significant at the 5 percent level.

**Significant at the 1 percent level. 
Table $3 \mathrm{~A}$

Unemployment Rate Results, Disaggregated by Individual Forecasts

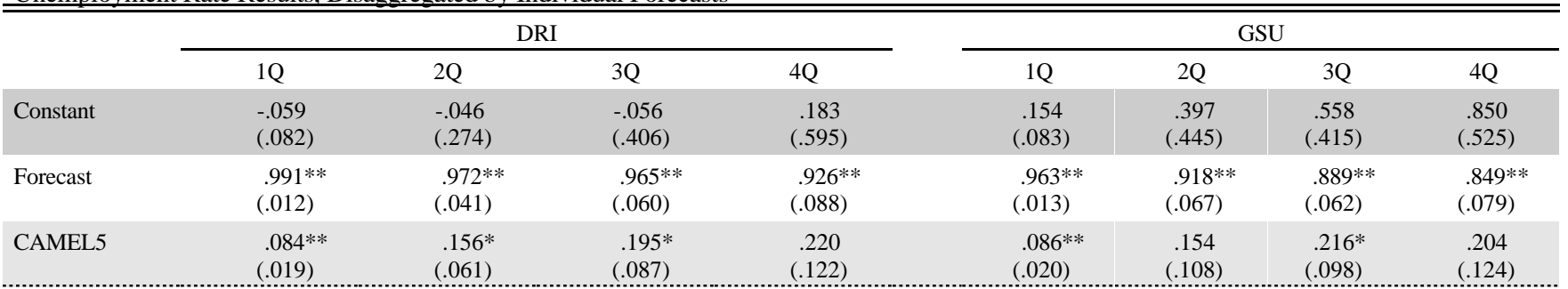

\begin{tabular}{|c|c|c|c|c|c|c|c|c|}
\hline & \multicolumn{4}{|c|}{ RSQE } & \multicolumn{4}{|c|}{ Blue Chip } \\
\hline & $1 \mathrm{Q}$ & $2 Q$ & $3 Q$ & $4 Q$ & $1 \mathrm{Q}$ & $2 Q$ & $3 Q$ & $4 Q$ \\
\hline Constant & $\begin{array}{l}-.082 \\
(.109)\end{array}$ & $\begin{array}{l}-.095 \\
(.294)\end{array}$ & $\begin{array}{l}-.076 \\
(.651)\end{array}$ & $\begin{array}{l}-.471 \\
(.639)\end{array}$ & $\begin{array}{l}-.092 \\
(.087)\end{array}$ & $\begin{array}{l}-.139 \\
(.316)\end{array}$ & $\begin{array}{l}-.223 \\
(.440)\end{array}$ & $\begin{array}{l}-.123 \\
(.576)\end{array}$ \\
\hline Forecast & $\begin{array}{l}.984 * * \\
(.016)\end{array}$ & $\begin{array}{l}.956^{* * *} \\
(.042)\end{array}$ & $\begin{array}{l}.942^{* *} \\
(.094)\end{array}$ & $\begin{array}{l}.993^{* *} \\
(.093)\end{array}$ & $\begin{array}{l}.992^{* *} \\
(.013)\end{array}$ & $\begin{array}{l}.977 * * \\
(.046)\end{array}$ & $\begin{array}{l}.975^{* *} \\
(.064)\end{array}$ & $\begin{array}{l}.958 * * \\
(.085)\end{array}$ \\
\hline CAMEL5 & $\begin{array}{l}.115^{* *} \\
(.019) \\
\end{array}$ & $\begin{array}{l}.247 * * \\
(.072) \\
\end{array}$ & $\begin{array}{r}.342 * \\
(.149) \\
\end{array}$ & $\begin{array}{c}.396 * * \\
(.139) \\
\end{array}$ & $\begin{array}{l}.107 * * \\
(.021) \\
\end{array}$ & $\begin{array}{l}.205 * * \\
(.074) \\
\end{array}$ & $\begin{array}{l}.297 * * \\
(.099) \\
\end{array}$ & $\begin{array}{c}.329 * * \\
(.124) \\
\end{array}$ \\
\hline
\end{tabular}

Note: The standard errors in the two quarter-ahead-forecast equation are corrected for MA(1) errors; the threequarter-ahead-forecast equation is corrected for MA(1) and MA(2) errors; and the four-quarter-ahead forecast equation is corrected for MA(1), MA(2), and MA(3) errors.

Standard errors are in parentheses.

* Significant at the 5 percent level.

**Significant at the 1 percent level. 
Table 3B

Inflation Rate Results, Disaggregated by Individual Forecasts

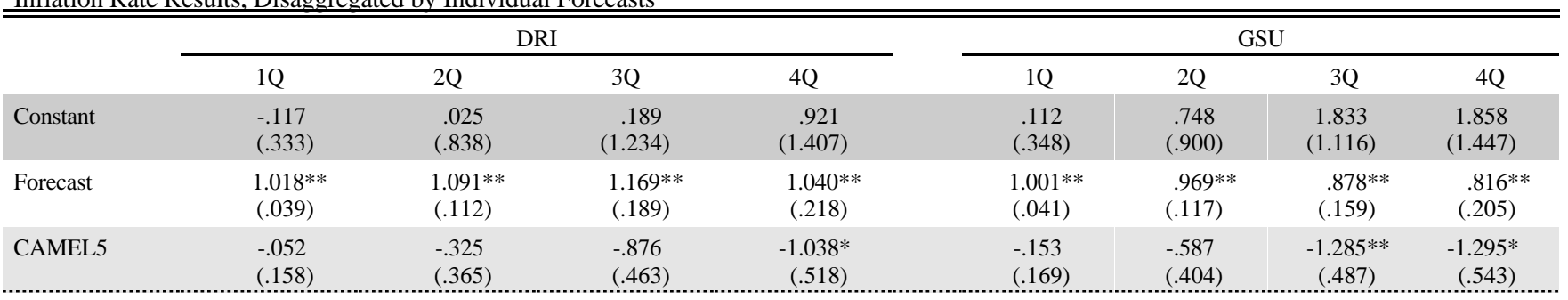

\begin{tabular}{|c|c|c|c|c|c|c|c|c|}
\hline & \multicolumn{4}{|c|}{ RSQE } & \multicolumn{4}{|c|}{ Blue Chip } \\
\hline & $1 \mathrm{Q}$ & $2 \mathrm{Q}$ & $3 Q$ & $4 Q$ & $1 \mathrm{Q}$ & $2 \mathrm{Q}$ & $3 Q$ & $4 Q$ \\
\hline Constant & $\begin{array}{l}1.102 * \\
(.464)\end{array}$ & $\begin{array}{l}1.201^{*} \\
(.543)\end{array}$ & $\begin{array}{c}.898 \\
(.669)\end{array}$ & $\begin{array}{l}1.369 \\
(.721)\end{array}$ & $\begin{array}{l}-.528 \\
(.309)\end{array}$ & $\begin{array}{l}-.128 \\
(.597)\end{array}$ & $\begin{array}{c}.402 \\
(.785)\end{array}$ & $\begin{array}{c}.467 \\
(.954)\end{array}$ \\
\hline Forecast & $\begin{array}{l}.668^{* * *} \\
(.063)\end{array}$ & $\begin{array}{l}.666^{* *} \\
(.079)\end{array}$ & $\begin{array}{l}.684^{* *} \\
(.104)\end{array}$ & $\begin{array}{l}.540^{* *} \\
(.112)\end{array}$ & $\begin{array}{l}1.803 * * \\
(.043)\end{array}$ & $\begin{array}{l}.965^{* *} \\
(.090)\end{array}$ & $\begin{array}{l}.872^{* *} \\
(.128)\end{array}$ & $\begin{array}{c}.865^{* *} \\
(.159)\end{array}$ \\
\hline CAMEL5 & $\begin{array}{c}.070 \\
(.244) \\
\end{array}$ & $\begin{array}{l}-.112 \\
(.271) \\
\end{array}$ & $\begin{array}{l}-.178 \\
(.295) \\
\end{array}$ & $\begin{array}{l}-.188 \\
(.300) \\
\end{array}$ & $\begin{array}{l}-.032 \\
(.147) \\
\end{array}$ & $\begin{array}{c}-.102 \\
(.259) \\
\end{array}$ & $\begin{array}{c}-.324 \\
(.308) \\
\end{array}$ & $\begin{array}{l}-.471 \\
(.347) \\
\end{array}$ \\
\hline
\end{tabular}

Note: The standard errors in the two quarter-ahead-forecast equation are corrected for MA(1) errors; the three-quarter-ahead-forecast equation is corrected for MA(1) and MA(2) errors; and the four-quarter-ahead forecast equation is corrected for MA(1), MA(2), and MA(3) errors.

Standard errors are in parentheses.

* Significant at the 5 percent level.

**Significant at the 1 percent level. 
Table 4

Determinants of Forecasts of Unemployment and Inflation Corrected for Moving Average and Contemporaneous

Correlations - Excluding 1988:II - 1991:III

\begin{tabular}{|c|c|c|c|c|c|c|c|c|}
\hline & \multicolumn{4}{|c|}{ Unemployment } & \multicolumn{4}{|c|}{ Inflation } \\
\hline & $1 \mathrm{Q}$ & $2 \mathrm{Q}$ & $3 \mathrm{Q}$ & 4Q & $1 \mathrm{Q}$ & $2 \mathrm{Q}$ & $3 \mathrm{Q}$ & $4 \mathrm{Q}$ \\
\hline Constant & $\begin{array}{c}.064 \\
(.111)\end{array}$ & $\begin{array}{l}.165 \\
(.351)\end{array}$ & $\begin{array}{l}.168 \\
(.621)\end{array}$ & $\begin{array}{l}-.052 \\
(.732)\end{array}$ & $\begin{array}{c}.415 \\
(.364)\end{array}$ & $\begin{array}{c}.714 \\
(.706)\end{array}$ & $\begin{array}{l}1.063 \\
(.941)\end{array}$ & $\begin{array}{c}1.432 \\
(1.126)\end{array}$ \\
\hline Forecast & $\begin{array}{l}.973 * * \\
(.017)\end{array}$ & $\begin{array}{l}.941 * * \\
(.054)\end{array}$ & $\begin{array}{l}.936 * * \\
(.094)\end{array}$ & $\begin{array}{l}.973 * * \\
(.111)\end{array}$ & $\begin{array}{l}.930 * * \\
(.042)\end{array}$ & $\begin{array}{l}.950 * * \\
(.091)\end{array}$ & $\begin{array}{l}.944 * * \\
(.136)\end{array}$ & $\begin{array}{l}.841^{* * *} \\
(.163)\end{array}$ \\
\hline CAMEL5 & $\begin{array}{l}.091 * * \\
(.028) \\
\end{array}$ & $\begin{array}{c}.174 * \\
(.086) \\
\end{array}$ & $\begin{array}{c}.201 \\
(.146) \\
\end{array}$ & $\begin{array}{r}.125 \\
(.177) \\
\end{array}$ & $\begin{array}{l}-.227 \\
(.201) \\
\end{array}$ & $\begin{array}{l}-.731^{*} \\
(.360)\end{array}$ & $\begin{array}{c}-1.184 * * \\
(.442)\end{array}$ & $\begin{array}{c}-1.273 * * \\
(.486) \\
\end{array}$ \\
\hline
\end{tabular}

Note: The standard errors in the two quarter-ahead-forecast equation are corrected for MA(1) errors; the three-quarter-ahead-forecast equation is corrected for MA(1) and MA(2) errors; and the four-quarter-ahead forecast equation is corrected for $\mathrm{MA}(1), \mathrm{MA}(2)$, and $\mathrm{MA}(3)$ errors.

Standard errors are in parentheses.

* Significant at the 5 percent level.

** Significant at the 1 percent level. 